\section{Is Cinderella Back Among the Cinders? A Review of Early Childhood Education in the Early 1990s}

\section{CARMEN DALLI}

\section{Abstract:}

The nineties started out as a time of optimism for the early childhood education sector: the Before Five policies, including phased implementation of higher funding, had just come on stream; policies were put in place in the late 1980s to improve the quality of early childhood education and were coming to fruition. The 1991 budget dampened this optimism: early childhood funding was capped at 1990 levels and a period of retrenchment set in. This paper discusses early childhood education policies over the last three years and some of the issues that arise from these.

\section{Introduction: The Cinderella of the Education System}

Tn the mid-1980s, early childhood education was often described as the "Cinderella" of the education system (e.g., Burns, 1988). One reason for this was the low proportion of Vote: Education allocated to the sector (e.g., 1.8\% in 1986 Report of the Department of Education, 1987). Others included the inequitable funding arrangements for the various early childhood education services which had been supported by a collection of government departments, often on a one-off basis. Ensuring equity of access to early childhood services by all sectors of the community was seen as another major issue requiring positive political action (e.g., Burns, ibid; Dalli, 1990) and affordable services responsive to community needs were seen as the desired but still unattained objective. The discourse of "quality" early childhood care and education was becoming frequently heard (e.g., Meade, 1987; Smith \& Swain, 1988). The sector was staffed by people with diverse training backgrounds, a situation which on the one hand was seen to be advantageous, in terms of the richness of perspective this contributed, and on the other hand acted as a barrier to mobility in employment options across the sector. The status of early childhood work was perceived to be low and despite the recommendations of governmentcommissioned reports to rationalise the administration of early childhood education (e.g., State Services Commission, 1980) and to introduce integrated training for the early childhood sector (e.g., Legislative Chambers, 1985; Department of Education, 1986 $a, b, c)$ there was a strong feeling that early childhood education was definitely at the bottom of the heap: the Cinderella who could not afford a ball gown and who definitely had not been invited to the ball.

\section{Cinderella meets the fairy godmother}

In the latter part of the eighties, however, the picture started to change. In July 1986, the recommendation of the 1980 report of the States Services Commission that the administrative responsibility for childcare services be transferred to the Department of Education, became a reality. In 1988, three-year integrated early childhood training was introduced in colleges of education promising better quality education in centres, enhanced professionalism, and better hopes for a rationalised career structure. 1988 saw the publication of the Meade Report and in 1989 the Government responded with the policy document Before Five.

Before Five outlined the new administrative structures that would deal with early childhood educational services together with policies which promised to redress many of the funding inequities of the past. Most noteworthy was the decision to implement a four-stage plan of higher funding across the sector. As I have noted elsewhere (Dalli, 1992), these initiatives signalled to the early childhood sector that a change of policy was 
underway and moving in the direction of producing a high quality early childhood service where equity of access and of funding were ensured.

\section{Cinderella goes to the ball}

It was a time of optimism (for example Burns, 1989; Dalli, 1990). Anne Meade (1990) captured the mood of the time in the title of her paper: "Women and Children gain a Foot in the Door". She argued that the political gains made by early childhood in 1989 were made possible through the co-ordinated activities of women, unions, Maori and people from other ethnic communities who applied political pressure and optimum timing in supporting the officials inside the Beehive doing the detailed policy work required for Cabinet approval of new policies.

Early childhood centres were also caught up in the optimism and during 1989 and 1990 they buckled down to the task of drafting the charters that would give them access to the higher levels of funding promised in Before Five. Charters had to meet quality guidelines that specified higher standards of early childhood provisions than the minimal ones in The Education (Early Childhood Centres) Regulations (1990) which had just been promulgated. The quality guidelines were formally released to centres in mid-November 1990 (Ministry of Education, 1990a). Highlights from the guidelines included better staff:child ratios than the minimum standards in the regulations (1990) and the requirement to train untrained staff. When, in 1990, the first phase of the implementation of higher funding was completed, and some evidence of lower parental fees and improved salaries in some centres started to be visible, it was beginning to look as if early childhood education had indeed come of age and that maybe Cinderella would get to spend some time with her Prince Charming.

\section{The clock strikes midnight}

However, as it turned out, the optimism was short lived. The gains made in the years between 1986 to 1990 were swiftly undermined. Barely a month after the quality guidelines reached centres, and within weeks of the National Government coming into office, the quality guidelines were superseded by another document :"The Statement of Desirable Objectives and Practices" (Education Gazette, 1990). As Anne Meade and I have argued elsewhere (Meade \& Dalli, 1992; Dalli 1993a) this document immediately annulled the power of the quality guidelines to require higher standards for chartering purposes than those in the regulations. The minimal standards in the 1990 regulations suddenly became sufficient for chartering and the higher funding that chartered services were eligible for.

Hot on the heels of this event came the release of Government's Economic and Social Initiative (New Zealand, Prime Minister, 1990) which froze the staged implementation of higher funding for early childhood services at the 1990 levels. Another announcement was that the PSU (per session unit) scheme introduced in 1984 with the aim of having three trained teachers in all kindergartens by 1994, would be halted. This was followed by the unexpected and totally unnegotiated change of the kindergarten regulations to allow kindergartens to charge fees.

It was further announced that there would be seventeen reviews of education, four of which would be in early childhood education in the areas of (a) the property aspects of the 1990 regulations, (b) funding, (c) staffing, training and qualifications and (d) the Early Childhood Development Unit.

The mounting of these reviews so soon after what had seemed like the beginnings of the settlement of longstanding problems in the sector, raised grave concerns among early childhood educators. The sector had hoped for a respite from submission writing and for some time in which to consolidate the recent gains (e.g., Dalli, 1992). As Wells (1991b) comments, this, however, was not to be. The early childhood sector was kept in limbo waiting for the results of the reviews until the middle of 1991 when they were released as part of the 1991 Budget. The decisions of that Budget continue to reverberate through the early 
childhood sector and can be identified as major contributors to the problems which now face the sector.

It is these problems that raise the question in the title of this paper. My argument in this paper is that with the 1991 Budget, the clock struck midnight and Cinderella found herself dragged back once more to the cinders.

In the following sections I shall outline early childhood education policies since the 1991 Budget and some issues surrounding these policies.

\section{Early childhood education policies since the 1991 budget}

The policy decisions in the 1991 Budget were:

i the introduction of Parents as First Teachers, described as "a new parent education and support policy to assist parents in fulfilling their vital role as the first teachers of their child" (Smith, 1991, p. 16)

ii the reduction of the hourly rate of government funding for under two-year-olds in centres from $\$ 7.25$ to $\$ 4.50$ per child. (The savings that would accrue from this were to be diverted into a new childcare subsidy administered by the Department of Social Welfare.)

iii the introduction of bulk-funding of kindergartens from 1 February 1992

iv a change in minimal ratios for under two-year-olds in mixed aged group centres from 1:4 to 1:5

$\mathrm{v}$ a change in the number of training points that the person in charge of a centre is required to have from the pre-existing 80 points (equivalent to two-year training) to 100 points by 1995 . This revoked an earlier policy of requiring 120 points by 1995

vi the registration of kindergarten teachers became noncompulsory vii the minimum licensing standards for ratios and qualifications level in the regulations were to apply for chartering purposes

viii regulations were "eased to ensure that resources go into learning not buildings" (ibid, p. 16)

ix funding for advisory support for licensed or chartered early childhood services and for in-service training and development became contestable and as a result, the operating budget for the Early Childhood Development Unit (ECDU) was substantially cut (by \$1.047 million in the 1991/ 1992 financial year and by $\$ 3$ million in 1992/1993, [ibid, 1991, p. 40]).

The budget documentation also stated that a decision on the establishment of early childhood centres in high rise buildings had not yet been made and would be announced later.

Anne Meade and I have commented elsewhere on the impact of these decisions on early childhood centres (Meade \& Dalli, 1992; see also Meade, 1992) and argued that the effect of these decisions was to threaten the ability of the sector to act as a unified whole and the ability of the sector to offer a quality service. The unity of the sector was threatened by the decision to bulk fund kindergarten teachers' salaries, which soon resulted in the secession of four kindergarten associations from the national New Zealand Free Kindergarten Union, and by the decision to make advisory support and in-service training contestable. The ability to provide a quality service was threatened by the cutback in bulk funding for infants and toddlers, the cutback in the minimal ratios for under-two-year-olds from 1:4 down to 1:5 and the cutback in training impetus signalled by the change to a 100 point qualification requirement for persons in charge (Meade \& Dalli, 1992).

Following the 1991 Budget most early childhood educators went round in what could best be termed a state of shock. As people took stock of the damage, and centres once more re- 
adjusted their budgets to suit the leaner times ahead, one loss was partly retrieved from the budget debris. The requirement of a 120 point qualification was re-instated but postponed to the year 2000 for persons in charge of centres. A second change was the deferment of the tendering out of the Early Childhood Development Unit's (ECDU) advisory support service till 1992. The first change followed strong lobbying that occurred at the early childhood convention held in Dunedin in September 1991 and the second change was a result of court action taken by ECDU on the basis of a breach of contract by Government.

1992 began to see the reality of the 1991 Budget enacted. The reduction of funding for under-two year olds took effect on 1 February. The new Childcare Subsidy, administered by the Department of Social Welfare and funded from the savings made from the reduction of the under-twos' funding began on 2 February. Bulk funding of kindergarten teacher salaries started on 1 March. On 24 March the Minister of Education, Lockwood Smith, launched the pilot programme Parents as First Teachers in Auckland.

In the context of these changes, the 1992 Budget was a nonevent for early childhood education. Nothing was gained and nothing more lost. On 14 August, however, it was announced that a decision had been made to allow the establishment of childcare centres in high-rise buildings. It was perhaps an indication of the predominantly disheartened feeling of the time that hardly a murmur was heard in protest at this, despite the heat that is usually generated whenever the topic is discussed among New Zealand early childhood educators.

During 1993, policy initiatives in early childhood education were again negligible with the notable exception of the decision to expand the Parents as First Teachers programme to eight new locations and to target three of these specifically at Maori and Pacific Island families. The virtual silence in the Budget on anything else to do with early childhood education, however, was not a reliable indicator that the sector was to be left on autopilot.
A few days before the release of the 1993 Budget, a new review of early childhood funding was announced.

It is no surprise then that the early 1990s have already been termed the years of retrenchment (e.g., May, 1993). In June 1993 at the launch of the campaign for quality education in the early years organised by the New Zealand Educational Institute and the Combined Early Childhood Unions of Aotearoa (CECUA), I argued that in the last few years our nation seemed to have lost its commitment to high quality centre-based early childhood education (Dalli, 1993a). I shall consider some of the issues that have arisen in the wake of this loss in the next part of this paper.

\section{The Current Issues: Cinderella among the Cinders}

\section{Bulk funding of kindergarten teachers' salaries: The privatisation} of the kindergarten service?

The decision to introduce bulk funding was announced in the 1991 budget as a decision "to bring kindergarten funding and selfmanagement systems into line with those of all other early childhood services" (Smith, 1991, p. 16).

Just before the release of the 1991 Budget and the decision to introduce bulk funding of teachers' salaries, Clare Wells, at the time national president of the Combined Early Childhood Union of Aotearoa, gave an address to the New Zealand Free Kindergarten Union (NZFKU) annual conference (Wells, 1991) which in hindsight has turned out to be eminently prophetic. Wells said that the kindergarten service was facing some of the most significant challenges in its history and that these challenges arose out of a long-term plan by Treasury to reduce Government's responsibility for education and to establish a pure form of self-management and ultimately privatisation.

Wells traced the effect of the State Sector Act on employment procedures in the kindergarten service making these procedures very similar to the model used in the private sector (e.g., having all the conditions of service codified into an award document, 
which the kindergarten sector had never had before). This, she claimed, removed the service some distance from the rest of the education sector. The Before Five policies also made the kindergarten service generally subject to the same provisions as applied to the rest of the early childhood service. Three qualities still, however, distinguished the kindergarten service from the rest of the early childhood sector and ensured government responsibility for the service: the separation of bulk funding of teachers' salaries, the requirements of teacher registration and a national award system negotiated centrally. Wells commented that if government really wanted to shed its responsibility for the kindergarten service then these three qualities would be targeted next for removal. She warned the Kindergarten Union, the employer body of the kindergarten service:

Remove compulsory registration and the door is opened to the employment of untrained staff. Accept bulk funding of teachers' salaries and the decision regarding the employment conditions and levels of remuneration are yours. Accept bulk funding, and you will also be charged with the negotiation process. Given that, under the State Sector Act, you are required to be good employers, you might well welcome full control. On the surface it might seem fair enough, but ... the implication is that once charged with these responsibilities, there is no obligation for the government to provide the current level of funding, indeed any funding, to the service. The government will be able to say, "Pay for it yourself" - after all, you can charge fees. Once responsibility is devolved to such a degree there is little recourse if we don't make ends meet. (p. 7)

Two and a half years later, Wells' predictions have been borne out. One of the first casualties of bulk funding was the already mentioned secession, in December 1991, of four of the largest kindergarten associations from the NZFKU. It appears that the Auckland, Waikato, Wellington and Central North Island associations could not agree with the NZFKU on the administrative procedures for the operation of bulk funding and have formed their own Kindergarten Federation. The implications of this event for the unity of the service are many: there is no longer a unified voice to act for the whole kindergarten service: each association now conducts its own salary negotiations; many associations have gone off the central payroll and have set up their own administrative systems, duplicating effort and expense in the process. The Kindergarten Appointment Scheme is no longer national and can no longer be used as a quality control measure; the same applies for the disciplinary procedures which the service had in place.

In a survey commissioned by CECUA and the Auckland Kindergarten Association to investigate the initial impact of bulk funding, Wylie (1992) reports that although the study was done in the early days of the operation of bulk funding some effects were already being felt. She reports that after the introduction of bulk funding, just over half of the employing associations experienced budget deficits. Wylie notes that "reasonable staff ratios, reasonable salaries and conditions, and trained staff are all related to positive outcomes for children ... but associations may be faced with the sad dilemma of having to choose between them" (p. 32). She adds that "the survey shows a clear link between parental socio-economic status and the resources available to individual kindergartens" (p. 32) and that "equal input from government funding distributed to kindergartens on a uniform roll-based basis will not ensure equality of outcome for all children." Mitchell (1993) in talking about the impact of Government policy on kindergartens, has used the case of Kenningston Street kindergarten in Waiouru to illustrate how outcomes can be unequal from equal inputs. Because of its transient army population, Kenningston Street kindergarten could not attract an even level of funding on a regular basis and had been threatened with closure. The Ruahine Association to which the kindergarten belonged was not prepared to crosssubsidise it from resources gained for use by other centres. The kindergarten was eventually saved from closure by the Wanganui Association to which it now belongs. 
Other examples of problems kindergartens have been facing include the case of the Marlborough Association which has considered employing untrained staff as third teachers in kindergartens and in their mobile units, and the many cases of kindergartens which have had to raise their rolls to 45 children per session in order to attract more funding and increase their chances of meeting budget shortfalls. In the Central North Island Association, three kindergartens have been looking at closing because their rolls are not high enough. At the time of writing two of these, one in Kawerau and one in Murapara, look as if they will survive but the third, Etprick Place in Tokoroa, will close in 1994. In the first week of December 1993, the Auckland Kindergarten Association circulated all staff and parents/whanau/caregivers with a consultation survey offering four options the service can act upon in order to resolve the financial crisis it faced. The options considered were: charging fees, "reducing overheads" by employing untrained staff, increasing rolls to 45 children per session and introducing additional sessions.

Those familiar with the philosophy of the kindergarten service will immediately be aware that these options go against fundamental principles on which the service was founded, i.e., that kindergartens should be free and that they should only employ trained staff. The aim that it should be a service accessible to all who need it, another key principle of the movement, is also under threat now that kindergartens are considering charging fees, a move made possible through the unexpected and unnegotiatied change in regulations that occurred in December 1990. Clearly, all of Wells' warnings have come to pass: untrained staff are being employed, associations are carrying out their own negotiations, fees are being mooted and the Associate Minister of Education has said on radio that kindergartens have the ability to increase their funding by making their own decisions on changes to their service such as by increasing their contact time (Morning Report, 28.2.92 cited in Double Take, Apr 1992, Vol. 3, Issue 2). The government is clearly saying "Pay for it yourself".

\section{Training and qualifications}

There are major confusions in the field about the future of training and qualifications in early childhood education. As Anne Meade and I have noted elsewhere (Meade \& Dalli, 1992), in 1988 three-year training was introduced in colleges of education and a three-year preservice qualification or its equivalent has since become the benchmark to which early childhood practitioners aspire as a means of achieving a high quality service. Because of the employment implications which three-year training had for people already employed in the sector, a scheme of allocating points for different qualifications was developed as a way of enabling people without the three-year training diploma to progress to a three-year full-time course qualification, to the value of 120 points. Two-year training earned 80 points and one-year training 40 points (Ministry of Education, 1990b).

The scheme was approved by Cabinet on 31 July 1990 and explained in a document entitled "Early Childhood Qualifications and Training: a Blueprint for the Future" released on 2 August 1990. The Blueprint, as the document soon became known, specified how people at different point levels could upgrade to the 120 point level by 31 December 1994.

In July 1990, the New Zealand Qualifications Authority (NZQA) was established with responsibility for recognising training and training providers, and issuing equivalence reports. The NZQA, with the help of the Early Childhood Advisory Committee, was responsible for deciding which courses were worth which points. NZQA was also charged with crediting points for prior learning or work experience.

The allocation of points to existing qualifications and experiential level was particularly important because of its link to licensing and chartering requirements specified by the Ministry of Education. In 1990, when the Blueprint was first released, licensing requirements specified an 80-point qualification and chartering required 120 points; a flurry of accreditation and training activity ensued in the search for the attainment of licensing levels. 
The confusions started to develop when inconsistencies emerged in (a) the number of points that different people with the same qualifications were credited with by NZQA, e.g., NNEB (Nursery Nurses Examinations Board) certificate assessed at 40 points in September 1991 and 80 points in July 1992 (Haggerty, 1993) and (b) the way that NZQA handled the 100-point "grandparenting" provision in the Blueprint intended for those with earlier, shorter-course certificates and experience (Meade \& Kennedy, 1992). Meade and Kennedy comment that NZQA became "hung up on the need to cover a core of units and too often required individuals to undertake courses far in excess of the 20 points needed to be awarded a Diploma of Teaching equivalent" (p. 7)

These confusions were compounded when in the 1991 Budget it was announced that from 1995 licensing would depend on a 100-point qualification and not the previously specified 120 points. Later that year, 120 points were re-instated as the required level from the year 2000 (Meade \& Dalli, 1992; Haggerty, 1993).

The immediate effect of the 1991 Budget statement was to slow down the impetus in upgrading qualifications. In addition, it seriously undermined the status of three-year training or its equivalent as the benchmark quality qualification. With the quality guidelines relegated to non-mandatory status, the reduction in funding for under-twos, the deterioration in the minimum ratios for under-two-year olds and the erosion of support for the kindergarten service, the 100-points decision seemed like another nail in the coffin for the quality service the early childhood sector had so recently thought was in sight.

In the early childhood world, the use of the 100 points as the new licensing "benchmark" created further confusion on another count. Until the 1991 Budget, 100 points had been the credit level at which practitioners eligible for grandparenting had been automatically placed. There had not been a qualification equivalent to 100 points. It appears that NZQA received a "large number of letters and phone calls due to the announcement and confusion" (NZQA paper, 16.8.91 cited in Haggerty 1993) which in September 1991 prompted NZQA to contact early childhood groups and propose three possible revisions to the point system. NZQA asked for immediate responses and specified a deadline that many could not meet. In the event, the decision was made in October 1991 to re-instate the 120-points benchmark so the issue was settled - not before, however, scope for further confusion had been created by NZQA's well-meaning but fumbled attempt to consult the sector.

The sector's worries about training and qualifications do not, moreover, stop at the confusions created by the "moving frontiers" of licensing and equivalency points requirements. During 1993 there was intense concern about the processes that NZQA was following to devise early childhood unit standards and the likely outcome of the decision that there should be unit standards at levels 1-4 in addition to unit standards at levels 5-7.

Levels 1-4 equate to a national certificate roughly equivalent to a qualification at the end of compulsory schooling. The decision to develop early childhood unit standards at this level within the industrial wing of the NZQA framework led to fears that the end result of the levels 1-4 exercise and the levels 5-7 exercise would create a two-tier system of early childhood qualifications for work in centres. The concern was that the lower level qualification would not equate to training that is adequate for the quality practice the sector had been striving to attain for many years (e.g., Meade \& Kennedy, 1992; Haggerty, 1993). By placing levels 1-4 within the industrial (as opposed to the school) part of the framework, the implication was that the units were intended for use by the industry in training people for work in early childhood settings.

The provenance of the decision to have unit standards at levels 1-4 was unclear to many in the early childhood sector. Theoretically, these decisions are the responsibility of the "industry" which is represented by an advisory group called 
together by NZQA (Letter from NZQA to writer, 3 November, 1993). Many members of the NZQA early childhood advisory group, however, were clear that their views on the issue had not been sought nor space made during meetings for the issues to be aired (personal communications with advisory group members). Following numerous representations to NZQA about these concerns at the end of December 1993, the early childhood advisory group reached agreement with NZQA that there would be a three-month suspension of the process of writing unit standards. The three-month period was to be used by the advisory group to discuss the relationships of levels 1-4 and levels 5-7 and what qualifications were desirable for the sector.

Other issues in discussion relate to unit standards at levels 5-7. These levels are expected to equate with the existing benchmark of a three-year teacher education diploma. The challenge of devising unit standards at this level is to ensure that the narrow competency model NZQA is using does not threaten the overall integrity of the wholistic qualification that one would hope a teacher education qualification ought to be. Another challenge is to ensure that there is cohesion between unit standards 5-7 and the recently published draft curriculum guidelines for early childhood education: Te Whariki (Ministry of Education, 1993).

Involved in the issue of training and qualifications are a number of other factors that probably owe their existence to the new "marketisation" of education. Meade and Kennedy (1992) talk about a "proliferation of courses and providers since the establishment of NZQA in July 1990". Haggerty (1993, p. 25) quotes Linda Mitchell, national secretary of CECUA, as putting the total number of NZQA accredited training providers of early childhood courses at 49; some of the courses of these training providers have only been able to rate a 10 -point allocation by NZQA. (These do not include 8-point courses set up especially for equivalency upgrading [Haggerty, ibid]). Haggerty suggests that the market approach to training and accreditation probably accounts for a considerable shift in the parameters of early childhood training and qualifications and in the pedagogy of its delivery. This shift includes the range of training sites for these courses, and the large increase in the number of nanny training providers (24 new providers since July 1990).

Clearly, the early childhood education training scene is a far more complex one than it was at the start of the nineties. This has created a set of interests that are sometimes hard to reconcile and are threatening to put the sector at a greater risk of fragmentation than it has ever been in before.

\section{The reduction in funding for under-two-year-olds and the Childcare Subsidy}

The 1991 Budget stated that a new childcare subsidy was being considered to assist low-income parents (Smith, 1991, p. 16). The pre-existing childcare subsidy programme administered by the Department of Social Welfare would continue. The press statements that accompanied the release of the budget document quote the Associate Minister of Education as saying that the new targeted childcare subsidy would be funded from the savings made in the reduction of under-twos funding which was estimated to amount to around $\$ 18$ million. The new subsidy could be used by families to access childcare centres, family daycare and kohanga reo but not playcentres, kindergartens and playgroups which, presumably, were assumed to be free.

The subsidy came into effect on 2 February 1992. During 1992 and 1993 it was accessed via an application by the parent supported by an earning certificate from the parent's employer and verification of the child's attendance by the supervisor of the childcare, family daycare or kohanga reo service. Ongoing verification of attendance at the early childhood education service was sought from early childhood centres on the basis of a computer print-out sent each month by the Department of Social Welfare to early childhood services with families in receipt of the subsidy. The subsidies were made available at the rate of $\$ 65, \$ 45$ and $\$ 25$ per week depending on family income. 
In the 1993 Budget, changes to the new childcare subsidy were announced that narrowed the targeted group of eligible recipients for the subsidy to people on low incomes who are actively involved in paid employment, attending an educational institute or undertaking training. This group of people remained eligible for a maximum subsidy of 30 hours a week. The eligibility of other low income groups not involved in training or employment was reduced to nine hours. The impact of this change on the recipients of this subsidy (usually Domestic Purposes beneficiaries) has been studied in a research project funded by the Department of Social Welfare. At the time of writing the report had not yet been publicly released.

The impact of the childcare subsidy on early childhood centres, on the other hand, has not as yet been thoroughly studied. The early childhood sector has tended instead to give more attention to the effects of the reduction in funding for under-two-year-olds on quality, access and centre operation. Following the 1991 Budget announcement, the Combined Early Childhood Union of Aotearoa surveyed childcare centre managers (not including kohanga reo) on the expected effects of the reduction in funding; the effect of the introduction of the new childcare subsidy was a subsidiary question within this survey. Respondents were also asked what effects the one year of higher funding in 1990 had had on their centres. The report states that "many of the variables that were assisted by the 1990 increased funding are now those that will be cut back" (CECUA, 1991, p. 5). It concluded that the reductions in funding were expected to detract from the quality of service that childcare centres were able to offer and would impede access for some families. Respondents expected a cutting-back of staff:child ratios, an increase in parent fees for children under two years of age, an increase of parent fees for children over two-years old and a cutting back on building maintenance and/or upgrading.

The report also states that childcare operators saw the incometested childcare subsidy system as administratively complex and inefficient, an invasion of privacy and as promoting a barrier between rich and poor. They were also concerned that families in the middle-income brackets would miss out under this system and access for this group would be reduced. The report cautioned that this would threaten the substantial contribution that middle income families traditionally have made to childcare centres in terms of day-to-day running of the centre, help in fund-raising, work on management committees and on working bees and maintenance (CECUA, ibid).

A further survey on the effects of the 1991 reduction in funding was carried out by CECUA at the beginning of 1993. This survey particularly considered changes to staff conditions of work, rates of pay and changes to centre operation. The report of this survey is still in draft form but the results indicate that the expected trends identified in the earlier study were being realised in the first year of reduced funding. A trend towards having to work with larger groups of children and worse staff:child ratios was noted by $16 \%$ of respondents, $49.6 \%$ reported an increase in fees and $30.5 \%$ reported an inability to replace equipment or properly maintain grounds. In addition, $53.1 \%$ of respondents reported that in 1992 the number of children in their centre receiving the social welfare subsidy had increased. A further finding was that respondents working in private centres reported more negative effects from the reduction in funding than respondents working in centres classified as co-operatives, incorporated societies and charitable trusts (CECUA, 1993c).

The clear implication of the two CECUA studies is that the reduction in funding has indeed created conditions in centres which undermine the ability of centres to provide a quality service. Other implications arise from the finding that the number of children in centres whose parent/s received the childcare subsidy rose when the new 30-hour subsidy was introduced in February 1992; this suggests that when the subsequent cut in the subsidy from 30 hours down to 9 hours for beneficiaries who are not in training or employment comes into effect in 1994, the likely 
result will be further reduction of income to centres. The likely consequence of this is even further undermining of quality features of centres.

A further concern arising from the increased reliance of centres on the childcare subsidies as a source of funding is the focus it gives to childcare services as a "welfare" versus an educational service. The dichotomy between these two notions had been largely eliminated since the 1986 transfer of childcare administration to the educational domain and the introduction of three-year integrated training. The new conditions for the receipt of the childcare subsidy, which attaches the subsidy to being in training or employment, further strengthens this suggestion. The clear message in the modified conditions is that those in training or employment are justified in needing to use childcare services but those not in employment or training are not so justified and are best occupied in looking after their children. This rationale totally ignores the wealth of evidence that shows that good quality early childhood services have significant social and educational advantages for all children and more so for children from disadvantaged backgrounds.

It is also noteworthy that the childcare subsidy scheme, at a cost of $\$ 39$ million (Creech, 1993), had proven far more expensive than the $\$ 18$ million saved from the reduction of under-twos funding. This was clearly not the result that government would have intended from its 1991 budget cutbacks in early childhood education spending. In this context, the narrowing of the eligibility criteria for the childcare subsidy can be seen as a second bite at a cost-cutting exercise which had somehow gone wrong.

\section{The Parents as First Teachers programme}

The Parents as First Teachers (PAFT) programme was launched as a three-year pilot project by the Minister of Education on 24 March 1992. The 1993 Budget announced that the programme was to be extended to eight new sites, three of which would cater specifically for Maori and Pacific Island populations. The eight new programmes are to be managed under contract by the Early Childhood Development Unit (ECDU).

I have outlined the history and issues surrounding the introduction of the PAFT programme elsewhere (Dalli 1992; Meade \& Dalli, 1992). In 1993, the same issues are still in discussion: there is still scepticism that a need existed to purchase and import an overseas model to provide services which are already provided by different local groups; there are still questions about the financial resources being diverted to this programme at a time when existing services are experiencing severe cutbacks, and there is still mystification about why the programme was introduced without any consultation with the early childhood community.

The experience of one and a half years of the pilot project has brought to the fore additional issues. For instance, it is now clear that much of the material used in the original Missouri programme has to be customised for New Zealand consumption, necessitating lengthy and expensive copyright negotiations (Scott, 1993). It is also clear that the programme leaves much to be desired in terms of appropriateness for Maori (Pihama, 1993) and despite claims of "initial positive feedback from parents" (Education Gazette, Sept 1993) it is known anecdotally that the pilot projects were unable to attract and/or retain the participation of parents from Maori and Pacific Island backgrounds.

A further issue is that the pilot programme acquired too strong an identity of a health initiative, not the least because it was administered through the Plunket Society, a well-known health service for babies and infants. Furthermore, the Minister of Education has been quoted frequently as saying that PAFT will identify health problems such as otitis media with effusion (e.g., Pihama, 1993).

The eight PAFT programmes announced in the 1993 Budget are being mounted in a way that is clearly intended to overcome 
the problems experienced by the pilot programmes and to shift the public perception of the programme away from an exclusively health initiative to a more multi-disciplinary one (Garden, 1993). The shift of the PAFT contract from the Plunket Society to the ECDU is one indication of the latter intention. The efforts being made to obtain permission from the Missouri copyright holders to translate the PAFT materials to meet the particular needs of Maori and Pacific Island families indicate a welcome acknowledgment that models developed in one culture do not necessarily fit the needs of people in a different culture.

One must, however, wonder whether the simple translation of material will in itself prove sufficient to make the programme more acceptable to the targeted Maori and Pacific Island families. Method delivery is as important as content in ensuring acceptability of the programme. With PAFT, the concern has always been that the parent educators would be seen as the "expert" outsiders with the knowledge to teach parents to get it right (e.g., Dalli, 1992); it will be crucial that the delivery of the "customised" and "translated" programme be such as to ensure that it reflects the spirit of partnership between families/whanau and early childhood professionals characteristic of most locallygrown early childhood services in Aotearoa/New Zealand. Where Maori and Pacific Island families are the targeted populations, the additional consideration has to be that the programme does not become a tool of assimilation of these groups into the broader New Zealand culture with the attendant devaluing of the assimilated culture that accompanies this process.

It appears that the ECDU is aware of the pitfalls of an inappropriate delivery model for the programme and has committed itself to requiring parent educators to be qualified as early childhood practitioners (Scott, 1993). ECDU has also taken responsibility for collecting and producing some resources (over and above the Missouri supplied ones) to support parent educators as well as undertaking negotiation with Missouri to adapt and modify the Missouri manual (Scott, ibid).
These initiatives are to be welcomed, particularly since it appears that the programme, or a modification of it, is here to stay. The PAFT programme occupies pride of place in Education for the 21st Century, a discussion document published by the Ministry of Education which represents "the Government's vision of an education system that will provide, first, the foundations of education, second, the development of essential skills, and third, life-long learning." (Ministry of Education, 1993b, p. 3). Education for the 21st Century says that PAFT is a way of involving parents in breaking "the cycle of educational failure that afflicts too many New Zealand families" and that "The Government believes that New Zealand needs Parents as First Teachers, or a similar programme, as a foundation of any plan for a successful education system for the twenty-first century" (p. 10). In the National Party's 1993 pre-election manifesto, the extension of PAFT to a national provision accessible to all parents by 1998 was the first of only two policy intentions for early childhood education (the second was the implementation of the national curriculum guidelines). Significantly, the PAFT programme also appeared in the Labour Party's pre-election plan for education where it is stated that the current trial of PAFT would be evaluated and if the results were positive, then the programme would be retained. Clearly, there is political will to make the programme work. Equally clearly, any moves to make PAFT more appropriate to local conditions is to be encouraged.

\section{The 1993 review of early childhood funding}

News of a new review of early childhood funding was leaked out to the early childhood community shortly after the release of the 1993 Budget. The early childhood community was dismayed not just at the news of another funding review barely two years after the 1991 one, but at both the proposed process and the terms of reference of the new review.

The 1991 review of funding had resulted in the 1991 Budget reductions of funding. This was despite the opposition of the 
sector and more than 3000 submissions which apparently remained unread by the members of the review team, with two exceptions: Dr Crispin Gardiner, who later resigned from the review team and issued his own independent report, and a researcher who presented a report on the submissions much later than the results of the review (Gardiner, 1991; 1993). Gardiner (1993) argues that the current review, with its originally secret terms of reference, a membership that is largely not knowledgeable about early childhood education and a very short reporting-back time-frame, is "designed to push through a total reorganisation of the early childhood sector ... and is like a rerun of the process in early 1991."

CECUA (1993) have similar criticisms of the 1993 review. They note the lack of representation of early childhood organisations on the review team and that the terms of reference were written with no involvement from the early childhood sector (pp. 5-6). They also question the content of the terms of reference which ask fundamental questions about early childhood education that the sector had believed to have long been answered (see also Dalli, 1993b). CECUA argue that the real question facing the sector is how to ensure that the services that currently exist are of high quality and meet the diverse needs of families; this question, however, is not within the review team's terms of reference. CECUA also criticise the one-month time frame for submissions as inadequate (ibid, p. 5).

The report from the funding review was to have been finalised just after the 1993 general election. The unprecedented election result, however, resulted in a number of government policy projects being put on hold: the early childhood funding review report was one of these. The report is now due in February 1994.

The early childhood community awaits the results of this review with grave interest. Much has been lost since the Before Five reforms and there is an understandable fear that this review will drive the sector further into the direction of a user-pays service than is currently the case. There are concerns about increased use of targeted funding and about funding the users as opposed to the service providers. Another concern is the aim of the review to evaluate current funding in terms of its "effectiveness in meeting the Government's objectives for the early childhood sector as set out in Education for the 21st Century". Within this document early childhood education is discussed in terms of developing skills before school entry and in terms of learning goals.

The concern with these objectives is that they are too narrow and suggest a mechanistic view of education that does not reflect the wider goals that early childhood education in New Zealand has traditionally espoused. Forinstance, it has long been accepted that early childhood services benefit not only children but their families/whanau and especially women. Many women owe their return to education and the paid workforce to involvement with early childhood services such as Playcentre and kohanga reo; it is also part of the kaupapa of kohanga reo that the service is as much about whanau learning as about the mokopuna becoming fluent in te reo and being able to ensure the survival of Maori language and culture (Tawhiwhirangi, 1993). Early childhood education is thus also about adult education and about cultural transmission and survival: aims not made explicit in the early childhood education section of Education for the 21st Century.

One thing is certain about the result of the 1993 funding review: if nothing else, it will serve to clarify government's real position on the role it perceives for itself in the provision of early childhood education and on the value it places on it. It will also provide an answer to the question that logically follows from the one posed at the start of this paper: if Cinderella is back among the cinders, is she destined to remain there or will the prince come along to rescue her after all? 


\section{Two Positive Developments and Some Concluding Comments}

So far this paper has traced the path of early childhood education policy decisions taken in the early 1990s and argued that losses have been experienced by the sector that threaten to erode gains made at the end of the 1980s.

This somewhat dismal conclusion is not, however, a complete commentary on the state of early childhood education in the early 1990s, and this review would be incomplete if it stopped there. Two major positive developments occurred which need to be mentioned: the release of the draft early childhood curriculum guidelines and the initiation of a project to develop a code of ethics for early childhood education in Aotearoa/ New Zealand.

\section{The Draft Early Childhood Curriculum Guidelines}

Discussions about a curriculum for early childhood had been held during the 1980s in a number of in-service (Lopdell) courses organised by the then Department of Education but the contract to develop early childhood curriculum guidelines was let as part of the Ministry of Education's drive to develop a National Curriculum for schools (Carr \& May, 1993). The draft early childhood curriculum guidelines, Te Whariki, were released by the Ministry of Education in October 1993. The guidelines (Ministry of Education, 1993a) are the product of months of research and consultation (through working papers, seminars and meetings) with the early childhood sector by the co-directors of the project, Margaret Carr and Dr Helen May. The result is a document that reflects the philosophy of the different early childhood services in Aotearoa/New Zealand as well as the consensus of international scholarship on what constitutes a high quality curriculum for the early childhood years. Te Whariki has been hailed by the early childhood community for these qualities and for the way it acknowledges biculturalism in Aotearoa/ New Zealand (CECUA, 1993b). As a document it articulates many of the principles that underlie quality early childhood practice and thus makes a valuable contribution to raising public awareness of the professional nature of early childhood work (Dalli, 1993b). There is great support for the curriculum guidelines in the early childhood sector; it is now important that the Government make resources available for the guidelines to be workshopped with practitioners of all types of early childhood services so that they may truly become a tool for enhancing quality practice.

\section{The Early Childhood Code of Ethics}

The current project to develop a code of ethics for early childhood is sector-initiated and reflects the commitment of the sector to enhancing its professional standing. As I have noted elsewhere (Dalli, ibid), many people regard the existence of a code of ethics as one of the clearest indications of professionalism; a code of ethics is a statement of the standards of ethical practice that a profession aspires to and abides by and it is also public evidence that a profession takes its responsibility to uphold ethical standards seriously. In New Zealand, a start on discussing ethical standards in early childhood education was made at a Lopdell course organised by the Department of Education in 1988. The report from this course recommended that work on the code be continued by the Ministry of Education. This recommendation, however, was not picked up until the formation in early 1993 of a national working group of early childhood educators under the umbrella of the Federation of Early Childhood Education Organisations (FECEO) and OMEP-Aotearoa/New Zealand. ${ }^{1}$ The working group aims to launch the code at the Sixth Early Childhood Convention in September 1995.

Both the code of ethics project and the draft curriculum guidelines augur well for the enhancement of the status of early childhood work as a profession.

In conclusion, therefore, it seems fair to say that while the policy issues facing the sector at the end of 1994 strongly suggest that the sector is in danger of again finding itself the Cinderella of the education system, developments such as the curriculum guidelines and the code of ethics project indicate that despite the odds, some progress on improving quality early childhood education is still being made. 


\section{Notes}

1. This is the New Zealand branch of the World Organisation for Early Childhood Education. OMEP is the acronym for the French name of the organisation: Organisation Mondiale pour l'Education Préscolaire.

\section{References}

Burns, Valerie "Policy in Early Childhood Education; Issues and Developments". Unpublished paper presented at the Educational Administration Conference, Christchurch, 1988.

Burns, Valerie "Early Childhood in New Zealand: the quiet revolution." Paper presented at the 19th World Assembly and Congress, ERIC, 1989.

CECUA Survey of Childcare Centre managers. Reduction in Funding for under-two-year olds in childcare centres: effects on quality, access and centre operation. Wellington, 1991.

CECUA" Kindergarten Bulk Funding Causes Problems", in Double Take, 3, Issue 2, April 1992, p. 1.

CECUA (a) Submission to the Review of Early Childhood Funding, October 1993.

CECUA (b) "Conference explores curriculum", in Double Take, 4, Issue 5, December 1993, p. 1

CECUA (c) Draft Report of Childcare Staffing Survey, Wellington, 1993.

Creech, Wyatt Budget papers, 1993.

Dalli, Carmen "Early Childhood Education in New Zealand", in Early Child Development and Care, 64, 1990, pp. 61-70.

Dalli, Carmen "Policy Agenda for Children's Lives", in New Zealand Journal of Educational Studies, 27, No. 1, 1992, pp. 53-66.

Dalli, Carmen Address at the launch of the NZEI-CECUA campaign for quality education in the early years, in Te Karere, June 1993, 1, Issue 1, 1993 .

Dalli, Carmen "Are we a profession? The contribution of the curriculum guidelines and the need for a code of ethics". Address to the CECUA curriculum conference, Christchurch, October, 1993b.

Department of Education (a) Report of the Working Party on Childcare Training, Wellington, 1986.

Department of Education (b) Three Year Training for Kindergarten Teachers: a report of a Ministerial Working Party, Wellington, 1986.
Department of Education (c) Training and Qualification Structure in Early Childhood Care and Education: a report of a Lopdell National Course, Wellington, 1986.

Department of Education Report of the Department of Education, Wellington: Government Print, 1987.

Education Gazette "Early Childhood Centre Guidelines: a Statement of Desirable Objectives and Practices", A Supplement to the Education Gazette, 14 December 1990.

Garden, Carol, National Coordinator, Parent Education Programmes, personal communication, 1993

Gardiner, Crispin Review of Early Childhood Funding: independent report 1991.

Gardiner, Crispin "Early Childhood Funding again threatened by Treasury". Unpublished Press Statement, dated 18 October 1993.

Haggerty, Maggie "Will there be life after the Labyrinth? A study of recent developments in Early Childhood Training and Qualifications 1980-1993". Unpublished Masters paper, Victoria University of Wellington, 1993.

Labour Party Education: our Children, Our Future, Pre-election Policy Plan, 1993.

Lange, D Before Five, Wellington: Government Print, 1993.

Legislative Chamber Early Childhood Care and Education Forum, Wellington, 1985.

May, Helen "'From a floor to a drawer' a story of administrative upheaval. A Post-Meade reflection on early childhood Policy". Paper presented at the Second Research into Education Policy Conference, August 30-31, NZCER, Wellington, 1990.

May, Helen "The Impact of the 1991 Budget on Early Childhood Education". Political Comments to the Family Daycare National Conference, Hamilton, 9 August 1991.

May, Helen “When Women's Rights have come to stay, oh who will rock the cradle? Early Childhood Care and Education and Women's Suffrage 1893-1993". Keynote address, NZFKU Annual conference, Wellington July 23, 1993.

Meade, Anne “Quality Early Childhood Education" A paper delivered at the Taranaki early childhood mini-convention, New Plymouth, July 1987. 
Meade, Anne Education to be More: Report of the Early Childhood Care and Education Working Group, Wellington, Government Print, 1988.

Meade, Anne "Women and Children gain a foot in the Door" New Zealand Women's Studies Journal 6, No. 1/2, 1990.

Meade, Anne "Contestability in the special education and early childhood sectors: a mechanism for conferring equity?" in Manson, H. (ed) New Zealand Annual Review of Education 2:1992, Wellington: Faculty of Education, Victoria University of Wellington, 1993, pp. 93106.

Meade, Anne \& Dalli, Carmen "Review of the Early Childhood Sector" in Manson, H. (ed) New Zealand Review of Education 1:1991, Wellington: Department of Education, Victoria University of Wellington, 1992, pp. 113-132.

Meade, Anne \& Kennedy, Pam "Early Childhood Training and Qualifications - before and Beyond 2000. Double gain or theft of our intellectuality?" A paper given at the Qualifications for the 21st Century International Conference, Wellington, January 1992.

Ministry of Education (a) Conditions for the Receipt of the Early Childhood Bulk Fund, Wellington, 1990a.

Ministry of Education (b) Early Childhood Qualifications and Training: a Blueprint for the Future, Wellington, 1990b.

Education Gazette "Parents as First Teachers Programme", 72, No. 15, 1 September 1993.

Ministry of Education Te Whariki. Draft Guidelines for Developmentally Appropriate Programmes in Early Childhood Education, Wellington: Learning Media, 1993a.

Ministry of Education Education for the 21st Century, Wellington: Government Print, 1993b.

Mitchell, Linda "Back, against the wall. Staffing and the Quality of Early Childhood Education: the impact of Government Policy". Paper presented at the NZCER Invitational Seminar: "What is Government's Role in Early Childhood Education?" February 1993.

National Party The National Party's Education Policy, Pre-election Statement, 1993.

Pihama, Leonie A Critical Analysis of Parents as First Teachers, Unpublished Masters thesis. Auckland University, February 1993.
Scott, Kiri " The Parents as First Teachers programme". Presentation at the first Annual General Assembly of OMEP Aotearoa/New Zealand, 28 November 1993.

Smith, A. B. \& Swain, D. A Childcare in New Zealand, Wellington: Allen \& Unwin/Port Nicholson Press, 1988.

Smith, Hon L Education Policy: Investing in our People: Our Greatest Asset, Wellington: Government Print, 1991.

States Services Commission Report of the Working Group on Early Childhood Care and Education, Wellington: Government Print, 1980.

Tawhiwhirangi, Iritana "Measuring the Success of Kohanga Reo" in Te Puna Wai Korero, National Radio; Replay Radio, 13 November 1993.

Wells, Clare Address to the New Zealand Free Kindergarten Union Annual Conference, 21 June 1991a.

Wells, Clare "The Impact of Change: Against the Odds". Keynote address at the Fifth Early Childhood Convention, Dunedin, September 1991b.

Wylie, Cathy First Impressions: The Initial Impact of Salary Bulk Funding on New Zealand Kindergartens. Wellington: New Zealand Council for Educational Research, 1992.

\section{The author}

Carmen Dalli is a lecturer in Human Development and Early Childhood Education at Victoria University of Wellington. She is a member of a national working group developing a code of ethics for New Zealand early childhood education, and a member of the NZQA advisory group on ECE. She is currently working on her PhD on children starting childcare.

* Parts of this paper were presented at the 1993 NZARE conference held at the University of Waikato School of Education on 2-5 December 1993. 